\title{
Koperasi Sebagai Wahana Pembelajaran, Serta Pembentukan Perilaku Berkoperasi
}

\author{
Studi Kasus Pada Koperasi Mahasiswa Kota Bandung \\ Yuanita Indriani \\ Institut Manajemen Koperasi Indonesia \\ yuanita_indriani@ikopin.ac.id
}

\begin{abstract}
ABSTRAK
Mahasiswa termasuk generasi milenial yang jumlahnya mencapai hampir 60 persen dari total penduduk Indonesia, namun mahasiswa tidak paham dan tidak tertarik pada koperasi, padahal para pendiri bangsa menegaskan bahwa bangun ekonomi yang paling sesuai untuk rakyat Indonesia adalah koperasi. Terdapat indikasi bahwa mahasiswa tidak tertarik untuk berkoperasi melalui Kopma. Beberapa pertanyaan yang muncul adalah mengapa Koperasi Mahasiswa tidak menarik, apakah Kopma menjadi tempat belajar berkoperasi yang baik dan apakah mahasiswa yang telah menjadi anggota Kopma memiliki preferensi untuk mengembangkan koperasi kelak jika mereka bermasyarakat. Penelitian ini menggunakan metode kuantitatif, lokus penelitian adalah Kota Bandung, Jumlah Kopma sample adalah 5, ditetapkan secara Purposive. Hasil penelitian menunjukkan bahwa Kopma telah memberikan pengalaman berkoperasi bagi mahasiswa anggotanya, baik berupa pengalaman negatif maupun pengalaman positif; Mahasiswa yang mendapatkan pengalaman positif, memiliki kecenderungan tinggi untuk mereplikasi kegiatan berkoperasi di masyarakat.
\end{abstract}

Kata Kunci: Koperasi, Koperasi Mahasiswa

\begin{abstract}
University Students, are millennials, which makes up almost 60 percent of the total population of Indonesia, do not understand and are not interested in cooperatives, even though the founders of the nation emphasized that the most suitable economic structure for the Indonesian people is cooperatives. There are indications that students' interest in cooperating through Student Cooperatives is still minimal. Some of the questions that arise are: why Student Cooperatives are not attractive to students, whether Student Cooperatives is a good place to learn cooperative values, and whether students who have joined the cooperative have a preference for developing cooperatives in the future. This study uses quantitative methods, the locus of research is the city of Bandung, the number of Kopma samples is 5, determined purposively. Research respondents were students (as members, administrators and supervisors as well as managers). The results showed that Kopma had provided cooperative experiences for its members, and the experiences gained were in the form of negative experiences and positive experiences; Students who get positive experiences from Student Cooperatives have a high tendency to replicate cooperative activities in the community.
\end{abstract}

Keywords: Cooperative; Student Cooperative

\section{PENDAHULUAN}

Undang-Undang Dasar 1945 khususnya Pasal 33 ayat (1) menyatakan bahwa perekonomian Indonesia disusun sebagai usaha bersama berdasar atas asas kekeluargaan. Pasal 3 Undang-Undang No. 25 tahun 1992 tentang Perkoperasian, menegaskan bahwa tujuan koperasi adalah memajukan kesejahteraan anggota pada khususnya dan masyarakat pada umumnya, serta ikut membangun tatanan perekonomian nasional, dalam rangka mewujudkan masyarakat yang maju, adil, dan makmur berlandaskan Pancasila dan Undang-Undang Dasar 1945.

Koperasi mahasiswa (Kopma) merupakan bagian dari pelaku koperasi Indonesia, yang beranggotakan mahasiswa Perguruan Tinggi tertentu dimana koperasi tersebut didirikan. Keberadaan Kopma selain untuk kepentingan bisnis, juga sebagai wadah dan sarana belajar mahasiswa dalam mengelola suatu usaha. Bidang usaha Kopma biasanya berupa toko, kantin/kafe, layanan fotocopy dan ATK, dan sebagainya.

Data pada Forlap Dikti 2018 menunjukkan bahwa jumlah Perguruan Tinggi di Indonesia mencapai 4.694 unit, dengan jumlah mahasiswa 7.024.620 orang. Jika data tersebut dikaitkan dengan data Kementerian Koperasi dan UKM Republik Indonesia, bahwa pada tahun 2018 jumlah Kopma di seluruh Indonesia baru mencapai 526 unit, atau 
7,74 persen dari jumlah seluruh perguruan tinggi di Indonesia. Hasil observasi awal terhadap 5 Kopma di Jawa Barat, menunjukkan bahwa rata-rata jumlah mahasiswa yang menjadi anggota Kopma hanya mencapai kisaran 5 hingga 20 persen dari jumlah seluruh mahasiswa, dan jumlah anggota Kopma yang aktif hanya mencapai angka 10 hingga 30 persen dari total anggota Kopma, hal ini menunjukkan potensi pengembangan Kopma yang sangat tinggi.

Tujuan koperasi mahasiswa pada hakikatnya sama dengan koperasi lainnya yaitu menjadikan anggotanya dan masyarakat umum sejahtera serta ikut membangun tata perekonomian nasional untuk mewujudkan masyarakat adil dan makmur. Karakteristik anggotanya yang unik yaitu mahasiswa, menjadikan koperasi mahasiswa memiliki kelemahan dan juga kelebihan.

Mahasiswa termasuk generasi milenial yang jumlahnya mencapai hampir 60 persen dari total penduduk Indonesia, namun tidak paham dan tidak tertarik pada koperasi. Kenyataan yang menunjukkan bahwa jumlah Kopma pada Perguruan Tinggi hanya mencapai sekitar 7 persen dari total Perguruan Tinggi, dan jumlah mahasiswa yang menjadi Anggota aktif hanya mencapai 20 persen dari total anggota, hal ini mengindikasikan ketertarikan mahasiswa untuk berkoperasi melalui Kopma masih minim. Beberapa pertanyaan yang muncul adalah apakah Koperasi Mahasiswa memiliki daya tarik bagi mahasiswa, apakah Kopma menjadi tempat belajar berkoperasi yang baik dan apakah mahasiswa yang telah berkoperasi melalui Kopma memiliki preferensi untuk mengembangkan koperasi kelak jika mereka bermasyarakat.

\section{Kebaruan Penelitian}

Kajian ini merupakan sebuah terobosan dalam rangka mencari solusi dari berbagai masalah penumbuh-kembangan koperasi di masyarakat,karena:

1) Saat ini koperasi tidak diminati generasi millennial, karena berbagai anggapan yang cenderung negatif dan mengakibatkan koperasi mengalami masalah regenerasi;

2) Disadari bahwa jika tidak dilakukan pendekatan kepada generasi muda yang termasuk pada kelompok intelektual, dikhawatirkan pembangunan koperasi akan tersendat atau bahkan terhenti, karena masalah pembangunan koperasi sangat tergantung dari proses regenerasi;

3) Disadari bahwa Mahasiswa menduduki peran strategis dalam penumbuhkembangan koperasi, karena selain jumlahnya yang mencapai angka 5,8 juta orang, mahasiswa juga memiliki idealisme dan kemampuan intelektual tinggi juga termasuk generasi millennial.
4) Penempatan Mahasiswa sebagai change agent dan re-branding agent perkoperasian merupakan sebuah inovasi, sebagai strategi untuk menjaga keberlanjutan dan perkembangan koperasi Indonesia, selain juga untuk meningkatkan daya saing koperasi Indonesia, hal ini selaras dengan berbagai hasil penelitian terdahulu yang menyatakan bahwa:

a) Mahasiswa sebagai re-branding agent, keragaan koperasi saat ini menyebabkan koperasi tidak diminati oleh generasi muda, peran mahasiswa dalam berkoperasi melalui Kopma diharapkan dapat meningkatkan citra dan keragaan Kopma di mata masyarakat;

b) Mahasiswa merupakan kelompok generasi muda intelektual yang termasuk dalam kelompok kaum millennial, sangat cocok untuk menjadi agent of change koperasi, melalui peran aktif nya dalam pengembangan Kopma, baik dari aspek kelembagaan, usaha maupun pengelolaannya. Dengan penguasaan ilmu dan teknologi, diharapkan mahasiswa akan mampu meningkatkan citra koperasi yang tua dan kumuh serta 'tidak kekinian' dapat digantikan dengan penampilan yang lebih segar, progressif, dinamis, berbasis IT tanpa meninggalkan nilai dan prinsip koperasi.

\section{KAJIAN PUSTAKA}

Sebagai salah satu pelaku ekonomi, koperasi merupakan organisasi ekonomi yang berusaha menggerakkan potensi sumber daya ekonomi demi memajukan kesejahteraan anggota. Karena sumber daya ekonomi tersebut terbatas, dan dalam mengembangkan koperasi harus mengutamakan kepentingan anggota, maka koperasi harus mampu bekerja seefisien mungkin dan mengikuti prinsipprinsip koperasi dan kaidah-kaidah ekonomi.

Ciri utama Koperasi adalah pendidikan, dalam hal ini pendidikan koperasi ditempatkan sebagai salah satu prinsip koperasi, hal ini mengandung makna bahwa koperasi adalah tempat belajar.

Koperasi Mahasiswa (KOPMA) adalah koperasi yang pada umumnya Pengurus, Pengawas dan Anggotanya adalah mahasiswa, yang menjadi ciri utama adalah bahwa koperasi tersebut terkait dengan mahasiswa. Pengurus KOPMA adalah anggota yang telah ditunjuk dan disepakati oleh seluruh anggota dalam forum Rapat Anggota bahwa merekalah yang akan menjalankan organisasi dan bisnis koperasi. Kegiatan usaha koperasi mahasiswa adalah melayani kebutuhan mahasiswa, baik yang berhubungan langsung dengan proses pendidikannya pada Perguruan Tinggi, maupun kebutuhan yang sifatnya tidak langsung berhubungan dengan proses pembelajaran pada Perguruan Tinggi.

Sebagai sebuah Koperasi, Kopma memerlukan Pengawas. Pengawas adalah anggota koperasi yang 
telah ditunjuk dan disepakati oleh anggota bahwa merekalah yang akan mengawasi kerja pengurus Kopma, rujukan atau pedoman penetapan dan pemilihan Pengurus dan Pengawas adalah Anggaran Dasar dan Anggaran Rumah Tangga Kopma, Perguruan Tinggi dimana Kopma terbentuk, pada umumnya juga melakukan pembinaan, pendampingan dan pengawasan, mengingat bahwa terdapat kepentingan mahasiswa di dalamnya.

Sumber daya organisasi secara garis besar dapat dibedakan ke dalam dua kelompok, yaitu sumber daya manusia (human resources) dan sumber daya non manusia (non-human resources). Sumber daya manusia meliputi semua orang yang berstatus sebagai Anggota dalam organisasi yang masingmasing memiliki peran dan fungsi. Sumber daya manusia adalah potensi manusiawi yang melekat dan keberadaannya pada seseorang yang meliputi potensi fisik dan non-fisik.

Eksistensi sebuah organisasi sangat tergantung dari sumber daya manusia yang terdapat dalam organisasi tersebut, merupakan asset dan berfungsi sebagai modal (non-material atau non finansial) dan penggerak organisasi, dalam kaitannya dengan SDM Kopma, maka mahasiswa sebagai anggota Kopma merupakan modal non material koperasi dan pengembangan koperasi di masa mendatang.

Pernyataan ini diperkuat oleh Sunyoto (2012) yang memberi penegasan bahwa sumber daya manusia merupakan faktor dominan, karena merupakan satu-satunya sumber daya yang memiliki akal, perasaan, keinginan, karsa, kebutuhan, pengetahuan, dan keterampilan, motivasi, karya dan prestasi. Sumber daya manusia adalah satusatunya sumber daya yang menentukan organisasi. Sumber daya manusia dipahami sebagai kekuatan yang bersumber pada potensi manusia yang berada dalam organisasi dan merupakan modal dasar organisasi untuk melakukan aktivitas dalam mencapai tujuan.

Sukamdiyo (2005) menjabarkan bahwa sumber daya manusia pada koperasi terdiri atas: Pengurus, Pengawas, Anggota dan Pengelola. Sukamdiyo menambahkan pengelola, atas pertimbangan bahwa pengelola menjalankan fungsi usaha koperasi, dan pengelola adalah professional, boleh bukan anggota. Undang-Undang RI nomor 25 tahun 1992 tentang Perkoperasian menggariskan perangkat organisasi koperasi adalah Pengurus, Pengawas dan Rapat Anggota, tanpa pengelola, karena pengelola diangkat oleh pengurus dan bertanggung jawab kepada pengurus, pengelola bertugas untuk menjalankan program-program yang disusun oleh pengurus dan disetujui dalam rapat anggota.

Sumber daya manusia koperasi yang digunakan dalam penelitian ini adalah pengertian perangkat organisasi koperasi yang digunakan dalam Undang-
Undang RI nomor 25 tahun 1992 tentang Perkoperasian, digabungkan dengan pendapat Sukamdiyo (2005). Karena dari pengertian tersebut mengandung makna bahwa yang dimaksud dengan sumber daya manusia koperasi, adalah Pengurus, Pengawas, Anggota dan Pengelola.

Ariffin (2013), mendefinisikan perusahaan koperasi adalah alat bagi anggota untuk mempertinggi efisiensi dan efektivitas di dalam mencapai tujuan ekonomi mereka. Perusahaan koperasi adalah perusahaan yang didirikan, dimodali, dan dikendalikan oleh para anggotanya, menunjukkan posisi anggota adalah pemilik perusahaan koperasi. Pada sisi lain, anggota memanfaatkan layananlayanan ekonomi yang diselenggarakan oleh perusahaan koperasi dalam rangka meningkatkan kondisi ekonomi anggota itu sendiri. Dalam hal ini berarti anggota berada pada posisi sebagai pelanggan dari perusahaan koperasi.

Penyelenggaraan pelayanan barang/jasa yang ditawarkan oleh koperasi harus memberikan pengaruh langsung maupun tidak langsung terhadap peningkatan nilai ekonomis bagi ekonomi rumah tangga anggota. Fungsi pelayanan yang harus dijalankan oleh perusahaan koperasi adalah untuk menunjang perbaikan ekonomi rumah tangga anggota, yang berarti fungsi pelayanan perusahaan koperasi harus berkaitan dengan fungsi ekonomi yang dijalankan oleh rumah tangga anggota (Ariffin, 2013).

Pernyataan Ariffin sejalan dengan pernyataan Hanel (1998) yang menyatakan bahwa koperasi sebagai suatu sistem sosio-ekonomi, dalam hal ini perusahaan koperasi harus dapat memenuhi kebutuhan ekonomi anggotanya, jika kegiatan usaha koperasi adalah usaha simpan pinjam, maka kegiatan usaha simpan pinjam yang diselenggarakan oleh koperasi harus dapat menunjang kegiatan ekonomi anggotanya.

Sugiyanto (2012) menyatakan bahwa keberhasilan usaha koperasi harus dibedakan antara keberhasilan sebagai perusahaan dan keberhasilan koperasi sebagai penunjang perusahaan individu anggota (member economy), hal ini sejalan dengan pendapat Dülfer, (1994:587) sebagai berikut: a further problem concerns content and measurement of the success of co-operation in the co-operative organization (assessment of success) .... A distinction must be made between the success of the cooperative enterprise and cooperative success of the single member enterprise of member economy.

Pendapat Sugiyanto dan Dülfer, akan mudah diukur pada anggota koperasi yang memiliki anggota yang memiliki kegiatan usaha individu, dimana koperasi memenuhi kebutuhan sarana produksi bagi usaha yang dijalankan anggota, memasarkan produk yang dihasilkan anggota, memenuhi kebutuhan tambahan modalnya atau hal lain yang sesuai 
dengan tujuan pendirian koperasi. Dengan demikian keberhasilan koperasi dalam memberikan layanan usaha kepada anggotanya diukur dari seberapa besar koperasi tersebut menghantarkan manfaat bagi anggotanya atau yang dikenal dengan cooperative effect (Yuyun Wirasasmita, 2012).

Hannel (1985), menyatakan bahwa keberhasilan organisasi koperasi dibagi menjadi tiga kriteria yang disebut sebagai tripartite, yaitu (1) Efisiensi dalam mempromosikan ekonomi anggota, (2) Efisiensi dalam menjalankan perusahaan koperasi dan (3) Efisiensi dalam memberikan sumbangan terhadap pembangunan sosial ekonomi masyarakat. Yuyun (2004), menegaskan bahwa manfaat koperasi bagi anggotanya tidak datang serta merta tanpa upaya dan rekayasa dari anggotanya, hal yang perlu diupayakan oleh koperasi dalam rangka memberikan manfaat kepada anggotanya. Kaidah penghematan yang dapat dijadikan landasan yang paling pokok dari kegiatan operasional organisasi koperasi.

Pembelajaran sebagai proses belajar yang dibangun oleh guru untuk mengembangkan kreativitas berpikir yang dapat meningkatkan kemampuan berpikir siswa, serta dapat meningkatkan kemampuan mengkonstruksikan pengetahuan baru. Pembelajaran juga menjadi sebuah upaya meningkatkan penguasaan yang baik terhadap materi pelajaran. Hal ini tentu berbeda dengan pengertian belajar, yang dapat diartikan sebagai sebuah upaya untuk memperoleh kepandaian atau ilmu, berlatih, berubah tingkah laku atau tanggapan yang disebabkan oleh pengalaman. Pembelajaran merupakan sebuah bantuan yang diberikan pendidik agar dapat terjadi proses perolehan ilmu dan pengetahuan, penguasaan kemahiran dan tabiat, serta pembentukan sikap dan kepercayaan pada peserta didik.

\section{METODE PENELITIAN}

Penelitian ini menggunakan metode kuantitatif, dengan responden mahasiswa yang menjadi anggota Kopma, yang dikelompokkan sesuai dengan perannya pada Kopma, baik sebagai Pengurus, Pengawas maupun Anggota. Informan yang memberikan kontribusi pada penelitian ini adalah Pembina Kopma baik Pembina Internal maupun eksternal.

Lokus penelitian ini adalah Kota Bandung, mengingat bahwa Kota Bandung merupakan Provinsi dengan populasi terbesar di Indonesia, dan jumlah perguruan tinggi di Kota Bandung mencapai 23 unit, dianggap mewakili gambaran perkotaan di Indonesia.

Jumlah Kopma sampel dalam penelitian ini adalah 5, ditetapkan secara Purposive. Responden penelitian adalah Mahasiswa (sebagai anggota, Pengurus dan Pengawas serta Manajer), penetapan informan dilakukan dengan metode simple random sampling.

\section{HASIL PENELITIAN DAN PEMBAHASAN}

\section{Aspek Kelembagaan Kopma Sampel}

Keragaan Kopma sebagai wahana pembelajaran yang pengukurannya difokuskan pada kedudukan Kopma di Perguruan Tinggi, sistem keanggotaan, manajemen keanggotaan dan kinerja kelembagaan Kopma dapat digambarkan sebagai berikut:

Tabel 1 Keragaan Kopma Sebagai Wahana Pembelajaran dari Aspek Kelembagaan

\begin{tabular}{|c|c|c|c|c|c|c|c|c|c|c|c|c|c|c|}
\hline \multirow[b]{2}{*}{ No } & \multirow{2}{*}{$\begin{array}{l}\text { Indikator } \\
\text { Kelem- } \\
\text { bagaan }\end{array}$} & \multicolumn{10}{|c|}{ Kompa Sampel } & \multirow[b]{2}{*}{$\begin{array}{l}\text { Skor } \\
\text { Ideal }\end{array}$} & \multirow[b]{2}{*}{$\begin{array}{c}\text { Skor Nyata } \\
\text { dan } \%\end{array}$} & \multirow[b]{2}{*}{ Kriteria } \\
\hline & & 1 & S & 2 & $S$ & 3 & S & 4 & S & 5 & S & & & \\
\hline 1. & $\begin{array}{l}\text { Status } \\
\text { Kopma }\end{array}$ & UKM & 14 & $\begin{array}{l}\text { UKM } \\
\& \text { Lab }\end{array}$ & 16 & UKM & 14 & Kom & 14 & UKM & 14 & 105 & $72(68,6)$ & Cukup \\
\hline 2. & $\begin{array}{l}\text { Sistem } \\
\text { anggota }\end{array}$ & SR & 21 & $\mathrm{SR}$ & 21 & SR & 21 & SR & 21 & SR & 21 & 105 & $105(100,0)$ & Baik \\
\hline 3. & $\begin{array}{l}\text { Man. } \\
\text { anggota }\end{array}$ & $\begin{array}{l}\text { Cat } \\
\text { mnl }\end{array}$ & 7 & $\begin{array}{l}\text { Cat } \\
\mathrm{mnl}\end{array}$ & 7 & $\begin{array}{l}\text { Man. } \\
\text { Data }\end{array}$ & 14 & $\begin{array}{l}\text { Cat } \\
\text { mnl }\end{array}$ & 7 & $\begin{array}{l}\text { Cat } \\
\text { mnl }\end{array}$ & 7 & 105 & $42(40,0)$ & Buruk \\
\hline 4. & $\begin{array}{l}\text { Kinerja } \\
\text { Kelem- } \\
\text { bagaan }\end{array}$ & Ttp & 7 & Naik & 18 & Ttp & 7 & Ttp & 7 & Ttp & 7 & 105 & $46(86,7)$ & Buruk \\
\hline \multicolumn{12}{|c|}{ Jumlah } & 420 & $265(63,1)$ & Cukup \\
\hline
\end{tabular}

Sumber: Data hasil penelitian diolah

\section{Masalah Kelembagaan Kopma Sampel}

Hasil survei menunjukkan indikasi bahwa pada umumnya kelembagaan Kopma sampel tidak berkembang atau bahkan cenderung menurun, hal ini ditunjukkan oleh berbagai hal sebagai berikut:
- Dukungan Perguruan Tinggi terhadap keberadaan Kopma sangat minim;

- Partisipasi mahasiswa sebagai anggota Kopma sangat rendah, hal ini terkait dengan pemupukan modal sendiri Kopma (simpanan 
pokok dan simpanan wajib) maupun partisipasi dalam pemanfaatan unit usaha;

- Pada umumnya Kopma tidak memiliki ketentuan yang jelas mengenai penghentian atau pemutusan status keanggotaan pada Kopma, sehingga terjadi akumulasi jumlah anggota tidak aktif dari anggota yang telah lulus dalam menempuh studi pada Perguruan
Tinggi yang bersangkutan, tanpa menyatakan keluar dari keanggotaan Kopma, hal ini pun terkait dengan akumulasi simpanan pokok dan wajib anggota pada Kopma;

\section{Keragaan Aspek Usaha Kopma Sampel}

Hasil penelitian mengenai keragaan Kopma sebagai wahana pembelajaran perkoperasian dari aspek usaha dapat digambarkan sebagai berikut:

Tabel 2 Keragaan Kopma Sampel Sebagai Wahana Pembelajaran Koperasi dari Aspek Usaha

\begin{tabular}{|c|c|c|c|c|c|c|c|c|c|c|c|c|c|c|}
\hline \multirow{2}{*}{ No } & \multirow{2}{*}{$\begin{array}{c}\text { Indikator } \\
\text { Usaha }\end{array}$} & \multicolumn{10}{|c|}{ Kompa Sampel } & \multirow{2}{*}{\multicolumn{2}{|c|}{$\begin{array}{c}\text { Skor } \\
\text { Nyata } \\
\text { dan \% }\end{array}$}} & \multirow[b]{2}{*}{ Kriteria } \\
\hline & & 1 & $\mathrm{~S}$ & 2 & $\mathrm{~S}$ & 3 & $\mathrm{~S}$ & 4 & $\mathrm{~S}$ & 5 & $\mathrm{~S}$ & & & \\
\hline 1. & $\begin{array}{l}\text { Kesesuaian } \\
\text { Usaha } \\
\text { dengan } \\
\text { Keb. } \\
\text { Anggota }\end{array}$ & $\mathrm{CS}$ & 10 & SS & 16 & $\mathrm{CS}$ & 12 & $\mathrm{CS}$ & 12 & $\mathrm{CS}$ & 10 & 105 & $60(57,1)$ & Cukup \\
\hline 2. & $\begin{array}{l}\text { Kepuasan } \\
\text { thd } \\
\text { Layanan } \\
\text { Usaha }\end{array}$ & $\mathrm{KP}$ & 8 & $\mathrm{P}$ & 17 & $\mathrm{KP}$ & 9 & $\mathrm{KP}$ & 8 & $\mathrm{KP}$ & 7 & 105 & $49(46,7)$ & Cukup \\
\hline 3. & $\begin{array}{l}\text { Trend } \\
\text { Omset }\end{array}$ & Ttp & 16 & Naik & 19 & Ttp & 15 & Ttp & 17 & Ttp & 14 & 105 & $81(77,1)$ & Baik \\
\hline $4 .$. & $\begin{array}{l}\text { Pangsa } \\
\text { Pasar }\end{array}$ & $\mathrm{K}$ & 7 & $\mathrm{C}$ & 16 & $\mathrm{~K}$ & 8 & K & 7 & $\mathrm{~K}$ & 7 & 105 & $45(40,0)$ & Cukup \\
\hline 5. & $\begin{array}{l}\text { Akses } \\
\text { Anggota } \\
\text { pd Kopma }\end{array}$ & M & 15 & SM & 19 & M & 14 & $\mathrm{M}$ & 13 & M & 14 & 105 & $75(71,4)$ & Cukup \\
\hline 6. & Harga & Mhl & 7 & $\mathrm{Sm}$ & 15 & Mhl & 7 & Mhl & 8 & Mhl & 8 & 105 & $45(42,8)$ & Cukup \\
\hline 7. & $\begin{array}{l}\text { Jejaring } \\
\text { Kopma }\end{array}$ & $\mathrm{TA}$ & 7 & TBT & 18 & $\mathrm{TA}$ & 7 & TA & 7 & TA & 7 & 105 & $46(43,8)$ & Cukup \\
\hline 8. & $\begin{array}{l}\text { Memodali } \\
\text { Kop }\end{array}$ & $\mathrm{R}$ & 7 & $\mathrm{C}$ & 15 & $\mathrm{R}$ & 7 & $\mathrm{R}$ & 7 & $\mathrm{R}$ & 7 & 105 & $43(40,9)$ & Cukup \\
\hline & & & & & Juml & & & & & & & 840 & $444(52,8)$ & Cukup \\
\hline
\end{tabular}

Sumber: Data Hasil Survey, diolah

Tabel 2 mengindikasikan bahwa Keragaan Kopma Sampel sebagai wahana pembelajaran perkoperasian bagi mahasiswa termasuk kriteria cukup, hal ini mengandung makna bahwa dari aspek usaha, Kopma belum optimal untuk dijadikan wahana pembelajaran perkoperasian bagi mahasiswa.

\section{Kopma Sebagai Wahana Pembelajaran Per- koperasian}

Hasil penelitian terkait dengan Kopma sebagai wahana pembelajaran dari aspek keuangan, diukur dari gambaran hasil penelitian terhadap Kopma sebagai wahana pembelajaran perkoperasian dari aspek keuangan dapat dilihat pada Tabel 3. 
Tabel 3 Penilaian Responden Mengenai Kopma Sebagai Wahana Pembelajaran Perkoperasian dari Aspek Keuangan

\begin{tabular}{|c|c|c|c|c|c|c|c|c|c|c|c|c|c|c|}
\hline \multirow{2}{*}{ No } & \multirow{2}{*}{$\begin{array}{c}\text { Indikator Aspek } \\
\text { Keuangan }\end{array}$} & \multicolumn{10}{|c|}{ Kompa Sampel } & \multicolumn{3}{|c|}{ Skor } \\
\hline & & 1 & S & 2 & S & 3 & $\mathrm{~S}$ & 4 & S & 5 & S & $\begin{array}{l}\text { Skor } \\
\text { Ideal }\end{array}$ & $\begin{array}{l}\text { Nyata } \\
\text { dan \% }\end{array}$ & Kriteria \\
\hline 1. & $\begin{array}{l}\text { Kepemilikan SOP untuk } \\
\text { penetapan dan } \\
\text { pembayaran SP dan SW }\end{array}$ & TA & 7 & SOP & 20 & TA & 8 & TA & 9 & TA & 7 & 105 & $51(48,6)$ & Cukup \\
\hline 2. & $\begin{array}{l}\text { Ketersediaan SOP } \\
\text { pengawasan Keuangan }\end{array}$ & $\mathrm{TM}$ & 7 & SOP & 17 & $\mathrm{TM}$ & 7 & TM & 7 & $\mathrm{TM}$ & 7 & 105 & $45(42,8)$ & Cukup \\
\hline & & & & mlah & & & & & & & & 210 & $96(45,7)$ & Cukup \\
\hline
\end{tabular}

Sumber: Data Hasil Penelitian, diolah

Permasalahan keuangan Kopma disebabkan oleh berbagai hal sebagai berikut:

- Pemupukan modal usaha Kopma sangat sulit, karena hanya memiliki satu sumber utama, yakni berasal dari simpanan pokok (anggota baru) dan simpanan wajib anggota, di lain pihak perkembangan jumlah anggota sangat terbatas dan cenderung tersendat;

- kemampuan dan kesadaran mahasiswa anggota untuk membayar simpanan wajib dapat dikatakan rendah. Hal ini mengakibatkan modal usaha Kopma sangat minim, yang mengakibatkan keragaan usaha yang tidak inovatif dan sukar berkembang.

\section{Manfaat Keberadaan Kopma}

Hasil penelitian menunjukkan bahwa keragaan Kopma sampel sebagai wahana pembelajaran termasuk kriteria cukup, hal ini mengandung makna bahwa keragaan kelembagaan, usaha, keuangan dan manfaat yang dapat diciptakan Kopma bagi anggotanya pada umumnya mengindikasikan belum baik, hal ini diperkuat dengan hasil penelitian dimana salah satu sampel menunjukkan keragaan yang cukup ekstrim jika dibandingkan dengan 4 kopma sampel lainnya.

Secara umum dapat disimpulkan bahwa sebagai wahana pembelajaran perkoperasian, Kopma belum representative, karena seharusnya wahana pembelajaran menunjukkan keragaan kelembagaan, usaha, keuangan dan manfaat yang baik, namun penelitian ini telah memberikan gambaran yang jelas bahwa sebagai wahana pembelajaran perkoperasian Kopma belum memenuhi standar, dengan asumsi bahwa standar wahana pembelajaran seluruh aspek seharusnya termasuk kriteria baik.

\section{Proses pembelajaran berkoperasi pada mahasiswa anggota Kopma}

Model pembelajaran berkoperasi mahasiswa melalui Kopma diilustrasikan melalui gambar berikut:

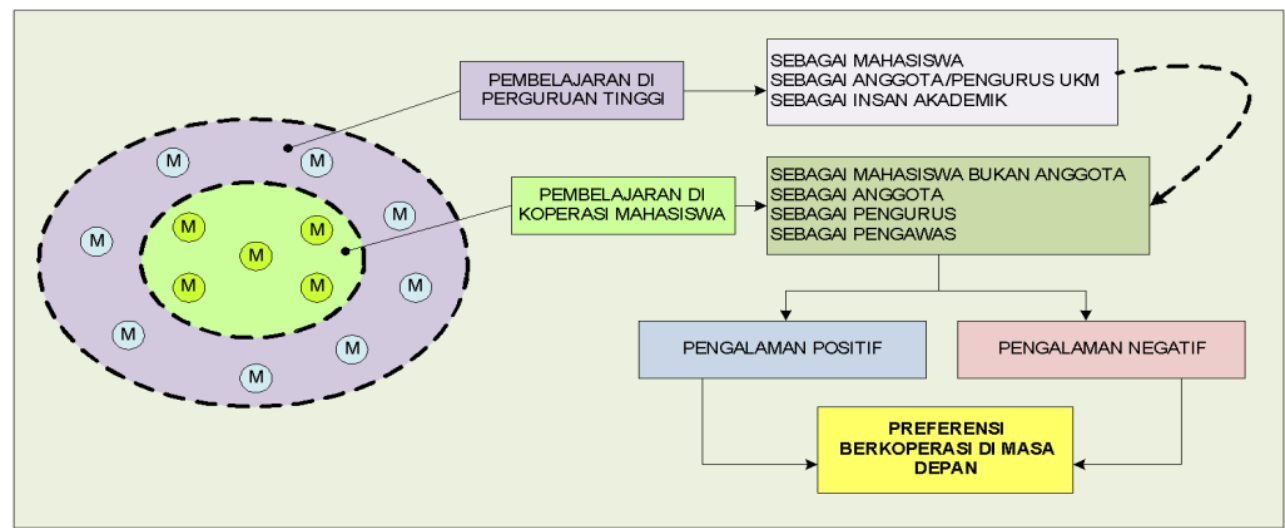

Gambar 1. Model Pembelajaran Mahasiswa pada Koperasi Mahasiswa

Pembelajaran Mahasiswa dalam berkoperasi, mengandung makna bahwa bagaimana Kopma dapat memberikan gambaran benak kepada mahasiswa mengenai berkoperasi. Hasil penelitian menunjukkan bahwa keragaan Kopma yang dijadikan sampel penelitian yang juga menjadi tempat pembelajaran mahasiswa dalam berkoperasi.

Mekanisme pemilihan Pengurus dan Pengawas 
Hasil kajian menunjukkan bahwa seluruh Kopma melakukan pemilihan Pengurus dan Pengawas melalui mekanisme Rapat Anggota, dalam hal ini forum yang digunakan adalah forum Rapat Anggota Tahunan (RAT), masa kepengurusan Kopma adalah 1 (satu) tahun.
Proses regenerasi Pengurus pada Kopma pada umumnya tidak terencana dengan baik, namun demikian dari 5 Kopma sampel, terdapat satu Kopma yang memiliki sistem regenerasi kepengurusan yang lebih terpola, yang secara umum dapat digambarkan sebagai berikut:

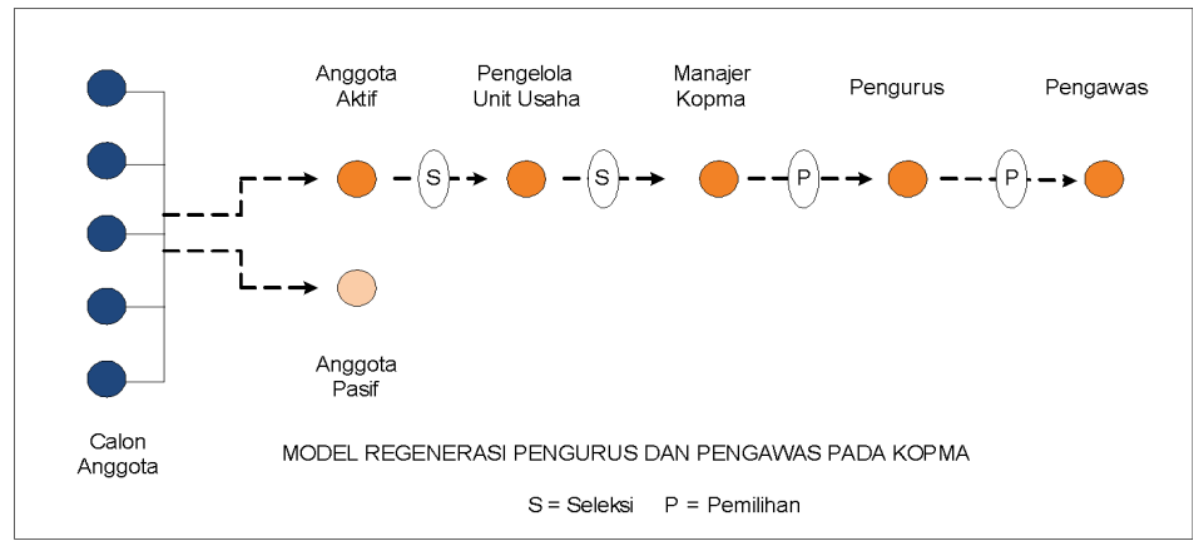

Gambar 2. Model Regenerasi Pengurus Kopma

Hasil penelitian menunjukkan bahwa terdapat indikasi telah terjadi proses pembelajaran di

\section{Prediksi replikasi berkoperasi}

Hasil penelitian menunjukkan bahwa pengalaman mahasiswa berkoperasi akan memberikan
Kopma, meski proses pembelajaran yang terjadi belum optimal.

gambaran benak kepada masing-masing mahasiswa tentang bagaimana berkoperasi, yang secara grafis dapat digambarkan sebagai berikut:

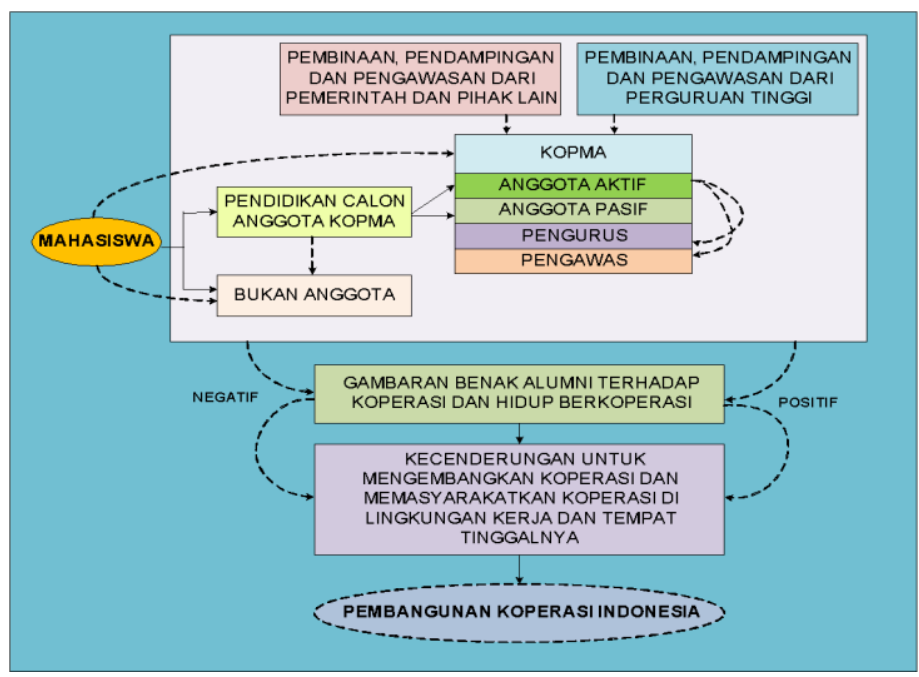

\section{Gambar 3. Gambaran Benak Anggota Tentang Koperasi dan dampaknya pada Replikasi Perilaku Berkoperasi}

Hasil penelitian menunjukkan bahwa seluruh mahasiswa yang dijadikan sampel memiliki kecenderungan positif untuk mengembangkan koperasi pasca mereka lulus. Hal ini didukung oleh pemahaman responden tentang Kebijakan Pengembangan Koperasi yang diperolehnya melalui berbagai kegiatan selama menjadi anggota Kopma.
Seluruh Responden menyatakan bahwa dukungan pihak Perguruan Tinggi dalam pengembangan koperasi dirasakan sangat minim, padahal hal tersebut sangat penting bagi eksistensi Kopma, hal ini mengindikasikan bahwa mahasiswa telah memahami berbagai kebijakan yang mendukung dan dibutuhkan dalam pengembangan koperasi, dalam hal ini bahwa pemahaman mahasiswa 
mengenai perkoperasian sudah dapat dikatakan tinggi.

\section{SIMPULAN}

Hasil penelitian menunjukkan bahwa Kopma telah menjadi wahana pembelajaran berkoperasi bagi mahasiswa yang tergabung dalam Kopma (baik sebagai Pengurus, Pengawas maupun sebagai Anggota), meski sebagai wahana pembelajaran, Kopma masih belum optimal.

Telah terjadi proses pembelajaran perkoperasian pada Kopma, meski belum efektif

Kopma telah memberikan pengalaman berkoperasi bagi mahasiswa anggotanya, dan pengalaman yang didapat berupa pengalaman negatif maupun pengalaman positif; Mahasiswa yang mendapatkan pengalaman positif dari Kopma memiliki kecenderungan yang tinggi untuk mereplikasi kegiatan berkoperasi di masyarakat. Peran Kopma dalam pembangunan Koperasi Indonesia ditunjukkan oleh preferensi mahasiswa anggota Kopma untuk mereplikasi kehidupan berkoperasi di masyarakat.

\section{DAFTAR PUSTAKA}

Blanchard Scott and Homan Madeleine, Coaching Secrets of The Top Executives, Alih Bahasa Ayu Soetopo Schiner, Penerbit PT Bhuana Ilmu Populer, 2004.

Dulfer Eberhard, The Cooperative between Member Participation, The Formation of Vertical Organization and Bureaucratic Tendencies, Quiller Press Ltd, London, 1985, copyright Phillips - University Marburg Germany.

Kementerian Koperasi dan UMKM Republik Indonesia, Laporan Hasil Penelitian Peran Kopma dalam Pembangunan Koperasi Indonesia, Jakarta, 2018.

Muchtar Irsyad, 100 Koperasi Besar Indonesia, Penerbit Majalah Peluang dan Infopasar, Jakarta, 2012.

Ritzer George, Goodman J Douglas, Teori Sosiologi Modern, Penerbit Kencana Jakarta, 2014.

Undang-Undang Nomor 25 Tahun 1992 Tentang Perkoperasian,

http://www.depkop.go.id/uploads/tx_rtgfiles/uu_19 92_25_perkoperasian.pdf

https://www.bps.go.id/dynamictable/2019/07/22/16 43/jumlah-koperasi-aktif-menurut-provinsi2006-2017.html https://propensitytoassume.blogspot.com/2014/10/k operasi-di-negara-maju-dan-berkembang.html

https://databoks.katadata.co.id/datapublish/2019/05 /14/berapa-jumlah-penduduk-di-pulau-jawa$\underline{2019}$

https://tumoutounews.com/2017/09/11/pendudukindonesia-terpusat-di-jawa-sumatera/ 